\title{
STRATEGIC COMPETITION, ECONOMIC DIPLOMACY \\ AND TRADE WARFARE: RE-CONCEPTUALIZING \\ THE 'COLD WAR' IN THE CASE OF RECENT US-CHINA TRADE WAR
}

\author{
Md. Nazmul Islam \\ Ankara Yildirim Beyazit University (AYBU) \\ Esra Eymen Cansu \\ Social Science University of Ankara (ASBU), \\ The Republic of Turkey Directorate of Communications, Ankara
}

\begin{abstract}
The present study proposes a method of analysis which contains the factor parts of re-conceptualizing of the Cold War within the aspects of economic, political, and technological interaction between the USA and China, which scholars denote as the 'New Cold War' and 'Post-Cold War', so that it will offer a source for further studies of the subject. This study outlines the 'new cold war' idea associated with problems of trade disputes between China and the USA that can be analyzed in each of the identified sub-cases. What this paper has endeavored is to define a method to establish a few extents of academic scholarship that would contribute to IR theories and to the literature to obtain new knowledge on the 'New Cold War' in the context of the recent China-USA Trade War. Our analysis pays more attention to American actions and China's reactions in the twenty-first century and more thoroughly covers the economic, political, security, trade, investment, and technological aspects. However, by employing the mainstream international relations theories, this paper attempted at describing how these fundamental forces shape the foreign policy in current and future external relations between and within the foreign policy-making process of China and the USA.
\end{abstract}

Keywords: Cold War, New Cold War, mainstream IR theories, Trade War, China, USA.

\section{Introduction}

After the fall of the Soviet Union and a journey of reunited Germany, the transformation of China came up to the world as 'Commu-Capitalist' hybrid nation and introduced a new turn in the political economy of international relations history. Scholars, like Edward S. Herman and Noam Chomsky (1988), observe that a new generation must learn the history since they have very little prior awareness of the transformation and changes in the international society occurring in the period from the late 1980s to the early 1990s. To understand the background and the foundation of this new trans-

Journal of Globalization Studies, Vol. 12 No. 2, November 2021 119-142

DOI: $10.30884 / j o g s / 2021.02 .06$ 
formation of the world, it could be agreed that it is essential to comprehend the history that shaped the contemporary world.

By clarifying Sir Lawrence Freedman (2019), this study addresses an alternative assessment of the national communication in the 'New Cold war' and post-former Cold World War era (Freedman 2019: 101-18). In this study we argue that the 'trade war' enlarged intensely because the strategic rivalry between China and the USA has been provoked at the regional and international levels. In this setting, the economic development and trade competition generated and facilitated new forms of conflict between China and the USA. These changes have a multi-dimensional impact on the discourse of bilateral and multilateral relations, crisis, war and character and the interface of conflict with the state in the modern world. However, to correlate with this account, this paper turns the field of international relations upside down and explores not just how the world has transformed to change the understanding of the crisis, but how the economic and political dynamics has transformed the world (in the context of competition). Accordingly, this study explores a conceptual and theoretical context of how that relationship has developed and how this new form of conflict between China and the USA might contribute to the future theories and empirical analysis of international relations studies, where the state relationship between China and the USA is considered as a stronger, more problematic and more destructive construction than is commonly predictable in the light of Sino-American competition in the discourse of new cold war.

\section{The Current Debates and Literature on the Recent Crisis Caused by the US-China Trade War}

The challenges faced by China and the USA have indeed caught the attention of scholars who have raised pertinent questions as to why these two countries' strategic competition leads them to trade crisis. The scholars define here the economic, political, technological, industrial, patent, historical, and cultural aspects. The American arguments in the US trade relations with China are not specific to the Trump era; and even in the studies of the early 2000s they are similar to the foreign policy outcomes produced by political elites during the Trump era. In his study titled 'A Trade War with China', Neil Hughes (2005) examined the USA's discomfort concerning the economic development of China in detail and drew attention to a possible trade war between the two actors.

As of 2018, Joshua P. Meltzer and Neena Shenai argued that the trade tensions between China and the USA continued to increase and primarily the Trump Government demands China to reduce its foreign trade deficit by up to $\$ 100$ billion (Meltzer and Shenai 2019: 1). On the other hand, M. M. K. Sardana (2018) identified the proposals such as creating new service sectors, reducing investment restrictions and purchasing more 'energy and agricultural products' from the USA, which China offered as a solution but which turned ineffective (p. 1). Moreover, although negotiations between Treasury Minister Steven Mnuchin and China's economy minister Liu, were held on the reduction of the foreign trade deficit by up to $\$ 200$ billion by 2020 , no results were achieved (Jakóbowski 2018: 2).

The tensions that have continued since 2018 and are called the 'Trade Wars' arise from the lack of dialogue between the USA and China and can be examined under three headings: Technology, Intellectual and Industrial Rights Wars, 'Steel and Aluminum 
Wars' and 'Automobile Wars' (Manish and Krishnan 2018: 10). In this context, the USA's Chinese policy is built on two bases parallel to each other. It is possible to classify these fundamentals as economic and political, while the economic policy comes as the first of these aims (Zhang 2018: 56). The investigation show that China's commercial practices caused the US companies to suffer from international trade which violates the intellectual rights of the US entrepreneurs (Demir and Tekir 2018: 36). Additionally, China's national security practices may control the most important technologies of the near future which is one of the possible political and security concern for the USA (Sirby and Arunachhalam 2018: 2).

However, Chad P. Bown and Melina Kolb (2020) argue how and why the trade war has started as the USA $v s$ others in the context of bilateral relations and strategic completion. They show that the trade war was started by the order of President Donald Trump who considered China's rise and 'trade war' as a 'national security threat' for the USA, so he imposed the tariffs on imports, which Bown and Kolb (2020) explained in terms of five strategic 'battles' between the USA and others, namely, 'Solar Panel and Washing Machine Imports Injure US Industries, Steel and Aluminum as National Security Threats, Unfair Trade Practices for Technology, Intellectual Property (IP), Autos as National Security Threat and Illegal Immigration from Mexico.'

Meanwhile, scholars like Suisheng and Guo (2019), Savinov with coauthors (2019), and Sinitsyn and Kuimov (2018) point out that Donald Trump led the USA to a direct breach of international law and multilateral agreements while seeking to 'make America great again' which was driven solely by political reasons. Accordingly, these some authors find out that the US 'protectionist foreign policy' has been referred to as the agenda of national interest in the sense of the idea of 'economic patriotism' concept and even 'economic terrorism'. The economic interests of economic and political institutions and informal unions of the country's allies are ignored. It has become clear that the USA is abandoning the idea and principle of free trade in order to maintain its position as the world leader, which will contribute to the proliferation of de-globalization processes in the world economy through the creation of regional mega-unions. The USA is not concerned in China's modernization, but the strong interdependence between countries appears to contribute to the growth of bilateral ties.

Some other scholars and institutes, like Rafi Sheikh (2018), Allison Carnegie (2018), Chunding, Chuantian, and Chuangwei (2018), Bouët (2018), and Grossman and Helpman (1995) analyze the US trade dispute with China and wonder how this battle can be fought. As Rafi Sheikh (2018) points, no trade war has the winner, but each trade war acknowledges three losers: all trading partners and global trade decline leading to global economic growth slowing down. Allison Carnegie (2018) defines the problems associated with Trump's escalation of trade war; while Grossman and Helpman (1995) turn their focus to trade war and trade talks. The current trade war between the USA and China often entails negotiations that have led to various compromises, especially from a highly secured Chinese market. Chunding, Chuntian, and Chungwei (2018) discuss the adverse effects of the trade war. In his essay, Bouët (2018) questions if trade wars are advantageous and whether they can be fought quickly.

Since the last couple of years, the trade war and the strategic competition between China and the USA have often elevated as a new area of scholarship for the literature of post-cold war international relations, foreign policy, and economic diplomacy. Yet, de- 
spite the importance of this academic subject, especially in the situation of America's growing ambitions and Chinese economic revolution, few scholars have sought to examine the possible scenario of US-China relations in major global events, especially, for the post-COVID-19 economy recovery and what academic contributions could be made to the mainstream IR theories by analyzing the foreign policy aspect of the USChina current relations.

The Mainstream IR Theories to Reconceptualize the Cold War, Strategic Competition and Trade War between China and the USA

Over the past thirty years, scholars, researchers and practitioners of international relations have been indicating a profound eastward shift in the economic activity (Kubalkova and Cruickshank 1986; Acharya and Buzan 2007, 2010; Piachaud 2008; Dadak 2010; Sadri and Burns 2010; Say 2012; Hove and Mutanda 2015; Olanrewaju and Joshua 2015; Sune 2016; Hove 2016; Ivanis, Dordevic and Jeftic 2016; Kaplan 2019; Islam 2019a, 2019b, 2020b; Sun 2019; Ferguson 2019; Trevelyan 2020; Rachman 2020; Islam and Cansu 2020; Nyadera and Islam 2020a, 2020b; Layne 2020; Hudson and Day 2020). Extrapolating to 2050, the global economy's gravity center will continue to shift eastward towards India and China. Within the framework of the shift in global economic gravity, the rising Asia and especially China's rise increased fears that China would destabilize the world order. While some prominent scholars warned of the coming conflicts and concerns about China's current foreign policy (Mearsheimer 2010; Yaqing 2010; Ari 2013; Islam and Cansu 2020), however, all those works are insufficient to explain China's peaceful rise and the US response to this rise (Buzan and Cox 2013). To clarify this question, we need to consider the main competing theories of the international system and how it operates.

Until the end of the Cold War, the Realist approach of the Asian IR were close to classical realism but have changed as a result of the end of bipolarity. Thereby, a new realist paradigm of Asian international relations argues that the end of bipolarity causes more instability and the end of the Cold War could lead to decompression of conflicts. As Kenneth Waltz (1979) emphasizes, the anarchic structure of the international system causes states to utilise self-help strategies in order to survive. These strategies allow the states to behave in an unrestricted manner. Hence, Waltz's neorealism asserts that China will also compete for power, territory and resources and defend its interests in order to survive similar to what other states do in this anarchic atmosphere. John Mearsheimer's offensive realism reveals an inevitable tendency of expansionism of the rising powers which according to the 'power transition' theory will likely lead to an inevitable confrontation between a status quo power (USA) and its rising power challenger (China). According to Mearsheimer, the "mightiest states attempt to establish hegemony in their region of the world while making sure that no rival great power dominates another region' (Mearsheimer 2006: 160). Thus, Mearsheimer believes that as a rising power China will seek to dominate and have no other way to secure its national interests unless it displaces the existing global leadership hegemon. For him, to protect its national interests China will continue militarization to have a policy stance towards the USA. At the end, the USA will have no any other choice except the confrontation with China if it wants to maintain its hegemony. Mearsheimer's (2001 and 2006) view on China's rise and his assertion about an inevitable war between the USA and China is mainly based on se- 
curity issues than on a non-militaristic aspect. On the other hand, there are other scholars (that could be called realist optimists) who express the importance of power but at that of China's limited power. Shambaugh (2004) states that China has neither an aspiration nor a capability to create a self-centered order. Also, Charles L. Glaser says that because of the relatively weak structural forces of two countries in terms of their power, intention, and information, the conflict will not occur between China and the USA. Additionally, he states the conventional attacks against each other are not possible because both counties have nuclear weapons and are separated geographically. The realist theories explain the China's rise by its growing military might; so John Mearsheimer argues that 'China will eventually be seduced by the opportunity to overtake the US hegemony and that China will not accept a subordinate role and thus support a multipolar world in order to free itself from US unilateralism' (Mearsheimer 2010: 387). To sum up, the realist theory is the most powerful source of fears of a rising China since the main assumption of the paradigm claims that the rising powers will cause disruption to the international system. Hence, considering the power transitions and their causes, the realists paint a dark picture of Asia's post-Cold War order and foresee that rising China will pose a challenge to the existing order characterized by the global American hegemony and disrupt the world order with its economic and military capabilities.

Within the realist international relations theories, there has emerged as a new version - Neoclassical realism which combines states' national policies with the analysis of resources or capacity in the international system and claims to explain the states' foreign policies. Within the realist approach the conflicts concerning the 'Balance of Power' theory used as a new assumption to explain the states' foreign policy actions. Neoclassical realists recognize that power is of primary importance in determining foreign policy (Wohlforth 1993; Rose 1998). They define power as the capacity of states to influence other states or the resources they can use for this purpose. Structuralist realism within the realist school exploits very few variables while explaining the phenomena of the international system. In contrast, neoclassical realism, as a foreign policy theory, claims to explain states' foreign policies and not the recurring phenomena in international relations. When analyzing the states' foreign policies, it includes the national political elements of the states in the analysis as well as the distribution of resources or capacity in the international system and thus, includes more variables. In order to understand the Chinese and US foreign policy action, it is necessary to have comprehensive knowledge about the states.

Nevertheless, the liberal paradigms of the international relations in Asia particularly emphasize the important role of interdependence as a force contributing to China's peaceful rise (Weede 2010: 209). They claim that the deepening interdependency and its durable impacts on both national and international politics are a crucial element of making China's rise peaceful. Similar to realism, liberalism also has its own tragic and optimist visions of the rise of China. The tragic parts of theory lay more emphasis on the domestic preferences of societies and reflection in the states' foreign policies. Liberalist scholars argue that to change the status quo the Chinese government may engage in activities which could lead to contradictions between China's political regime and the liberal international order. Some analysts believe that the increasing dissatisfactions and economic demands from the new middle class may bring China to an inevitable conflict with other states and companies and this may end with hardline policies. Besides, the theorists claim that rising nationalism, the fragility of China's domestic governance and 
domestic political unrest may derail China's peaceful rise. The optimists mainly have two assumptions - that the interests stemming from both inside and outside of China are not tending to conflict and besides those are collective interests rather than conflictual ones. They argue that China will increasingly accept the rules, norms and principles through integration into the international order and will eventually uphold the order. They assume the economic expansion of China will provide a better interaction and a web of non-state collective interests and foreign policies (Keller and Rawski 2007; Shambaugh 2004). Besides, some analysts predict that the liberalization of China's domestic policy will have an 'inside-out' spillover effect that will lead to a more cooperative Chinese foreign policy (Liu 2006: 63). G. John Ikenberry $(2008,2011)$ claims that as China continues its integration into the established international system, it also becomes a supporter of the order. Ikenberry writes that the web of multilateral institutions and security pacts in the global liberal order exposes states to cooperate with each other and become more integrated while building long-term multilateral and mutually advantageous relations. $\mathrm{He}$ claims that as China's integrationist strategy continues, she will no more seek for gaining authority or leadership. In contrast, the ongoing liberal international order will continue even if the United States were to refuse. Hence, he asserts that China and other emerging states will hardly attempt to change the basic rules and norms of the liberal international order established by the USA. The liberal theorists, including the Western ones, explain the rise of China through its economic power; they argue that the rise of China is a very optimistic benefit for the Southeast Asian region and the whole continent and it will provide excellent opportunities for the world economy. Additionally, the Chinese approaches through the international organizations will become an effective tool to support the balance of power and regional stability (e.g., the approaches of ASEAN and the ASEAN-China Free Trade Area legislation). At the end, Ikenberry (2008) briefly notes that 'the more institutionalized and encompassing the existing order is, the more difficult it is for a newly rising state to overturn it' which will end up with more integrated China and international system rather than any alternative order established by China (Ikenberry 2008: 92).

For the constructivists, the international relations are formed not only by material forces but also through sharing ideas and intersubjective understanding of material resources. To define the world order, the constructivist theorist underlines the important role of ideas, norms, history, cultures and identities which emerge and are shaped by social structures and interactions (Wendt 1992, 1995). Understanding the significance of those factors, constructivism furthers and advances the understanding of sources and determinants of Asia's international relations which cannot be clarified merely by materialistic perspective. However, there is no clarity what Wendt's $(1992,1995)$ theory offers about the rise of China, about its status quo or its revisionist power with respect to the Western IRT. However, the theory foresees conflicts or cooperation depending on how an idea or value-based differences emerge. One of the leading Chinese scholars of constructivism Qin Yaqing explains the rise of China with its distinction regarding norms and values 'based on the Chinese way of thinking, Chinese dialectics, and Chinese understanding of human society' (Yaqing 2010: 131). She claims that China can introduce its own understanding of norms and values and may try to revise the international system again according to its own norms and values in order to make its rise peaceful within the international culture that China constructs. Constructivism also suf- 
ficiently explains why a different form of regionalism is possible in Asia. Regarding the normative and cultural factors of the Asian states, constructivism reflects the emergence of regional institutions and dialogues in Asia after the Cold War. It explains the first regional grouping of Asia called ASEAN and its origins and evolution. Besides, constructivist theorists draw attention to fundamental ideational distinction between China and the dominant West; they also define the regional institutions of Asia and differentiate those Asian institutions from the Western-derived approaches. This paradigm also provides an alternative approach to Chinese scholars view because they do not consider the rise of China as a significant threat to the global order (Chin and Thakur, 2010) and international stability.

\section{Historical Roots, Trade War, and New Dimensions of the Cold War}

After the Second World War, the USA and USSR became two superpowers within the new world order. One nation tried to reduce the power of the other and so the two superpowers fought each other in many various ways, through full-scale nuclear threat, regional military conflicts, as well as espionage operations, national space race, and ideological warfare via propaganda. This competition between the superpowers indirectly led to the Cold War. At the end, America took the leadership of all the Capitalist Countries and Soviet Russia took the leadership of all the Communist Countries. As a result, both stood as rivals to each other.

Raymond Aron defined the Cold War system as the 'impossible peace, improbable war' because of the 'balance of terror' in the nuclear age (Aron 1972, 1976 and 1983; Hoffmann 1985; Campbell 1989; Moisi 2018). In contemporary world, some scholars say the new Cold War started with Donald Trump's election in November 2016, or his initial imposition of tariffs on imported technologies and other tools, many of which are produced in China, in January 2018. Others date the starting point already to October 2018, when Vice President Mike Pence declared Beijing's use of 'political, economic and military tools, as well as propaganda, to advance its influence' (Ferguson 2019). Besides the Trump administration's confrontational approach to China also effectively embraced by senators and political elites on both sides of the partisan divide and with the start of the trade war in 2019, the two sides of the new cold war rapidly confronted each other and argued about the American trade deficit and Chinese intellectual property theft.

\section{The 2008 Economic Crisis and Increasing Protectionism Policies as a Tool of Trade War}

Before the 2008 global crisis, liquidity surplus occurred in the world economy. China became a member of the World Trade Organization in 2001 and increased its competitiveness in the market by reducing the value of yuan. At the same time, the Far Eastern countries had invested their savings in the US financial instruments so the interest rates decreased due to the excess liquidity. The US economy has started to contract economically since 2006 and in 2009 this contraction even deepened. In the post-crisis period, the world economy had negative effects: the growth rate slowed down, the relationship of trust that deteriorated in the national and international economy had negative effects on exports and imports, and demand declined as capital owners left the countries. All these caused a decrease in the imports. In developing countries, the decreasing imports led to a decrease in exports accompanied with growing unemployment and decreasing 
demand, and the economic crisis gradually deepened with the contraction in trade volume especially in developing countries. States tried to improve their internal structures by taking various protective measures against stagnation in international financial markets that developed with the crisis. Within the scope of these policies, which form the basis of protectionism, states have implemented nationalization, interest rate reduction and support programs in order to protect the real market. Great powers were also affected differently by the crisis process. In this process, while the foreign trade deficits of the USA increased, the Chinese economy grew between 8 per cent and 10 per cent in the period of crisis (World Bank 2020). Therefore, the US economy started to contract during the 2008 crisis, but the Chinese economy grew during the crisis years. This is an indication of the US protection measures against China.

In the post-2008 crisis, great powers preferred different policies depending on their economic structure. Providing state welfare mostly due to foreign trade, China advocates free trade, but the USA, which has advanced and completed its industrialization, is a proapplication of protectionist policies. In this context, China aims at creating more free trade between countries by railways, highways and pipelines with the 'One Belt One Road Project'. On the other hand, the protectionist attitude of the USA, which has the biggest share in global trade, has been a sign that the level of protectionism will increase in the coming period. The increasing protectionism in question is seen as an important step in terms of trade wars. Today, at the stage we have reached in trade wars, the US administration is taking new measures to prevent trade by claiming that the trade deficit against China is growing.

\section{The US Protectionism Policy and Dimensions of the New Cold War}

'Protectionism' is a foreign trade policy based on the aspirations to defend the country's domestic producers against all kinds of destructive foreign competition. The most common advocated rationale for protectionism is to support an industry based on imports and gain competitive advantage in the long run. Although protectionism in foreign trade is mostly applied by the great powers, other states may also apply it. As foreign trade policies of states like the USA and China have further distorted the international system, it is reflected in the international press and academia. As countries maintain protectionism, the free price mechanism deteriorates, and problems arise in optimum resource allocation. As it will cause disruptions in the world economy in general, it may cause political disconnections between states and negatively affect globalization.

Many developed countries, including the USA, argue that globalization causes unfair competition and that less developed countries can sell their goods cheaper due to cheap labor. It is also thought that globalization brings freedom of movement and increases migration. After the 2008 crisis, we see that the anti-immigration and protectionism policy has grown in Western Europe and the USA. At the 2016 elections, Trump received some of its support from workers of the iron and steel and automobile industry, who thought it was harmed without globalization. When Donald Trump became president, he argued that developing countries such as Mexico were in unfair competition in trade and announced that he would implement the 'America First' target. At the same time, Trump suggested that the World Trade Organization was acting against the USA, and we can say that he opposed the organization that would implement a common policy in international trade. All this has led to USA to implement an economically protective 
policy. In this regard, the implementation of the protectionist trade policies, which Trump expressed with slogans like 'America First' and 'Make America Great Again,' may strengthen the USA's major rivals, especially China. Countries that play an important role in the global trade may turn to protectionist policies, which may bring down a possible contraction, currency and trade wars. For example, the US President Donald Trump announced that a 5 per cent customs duty would be imposed on products entering Mexico from the USA in May 2019. Trump used it as a threat to prevent immigrants from Mexico. But in fact, trade should be used as a mediating force rather than a threat between the two countries.

Along with the Covid-19 outbreak, with the decrease in world production, oil prices tended to decline rapidly, and oil wars started between Russia and Saudi Arabia. Saudi Arabia wanted to be the determinant of prices in order not to affect the sales of oil due to Covid-19. Saudi Arabia, whose economy is dependent on oil, wanted to increase its oil sales, albeit with less profit, by lowering prices. Russia, on the other hand, did not want to decrease oil prices without seeing economic effects. In this situation, the USA wanted other oil producing countries to increase their oil prices. Saudi Arabia continues to offer big discounts for its crude for the Asian buyers despite calling a truce in its global price war under pressure from the USA. Finally, the OPEC + countries reached an agreement, but this process was painful. Saudi Arabia and Russia blamed each other for the crash. Putin accused Saudi Arabia of trying to destroy shale; the Saudis said Moscow had kicked the whole thing off. None of it cut any ice in Washington. However, the fixing price has been seen as one of the factors that harm international cooperation and economy. In just a few weeks, the US oil prices fell by 34 per cent, crude oil 26 per cent and Brent oil 24 per cent (Blas 2020).

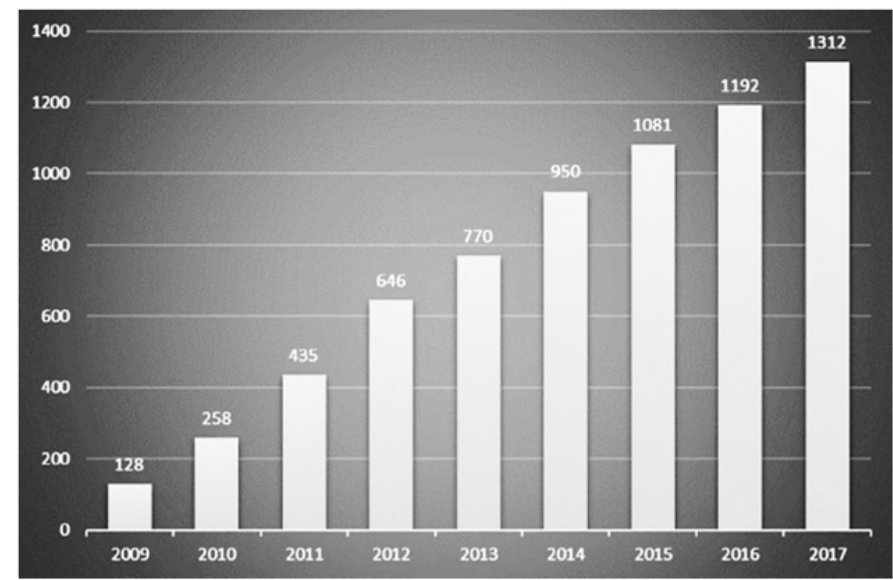

Fig. 1. The Number of Protective Measures Taken by the USA (PCS, 2009-2017)

Source: Global Trade Alert, 2018.

Developed countries have implemented new protectionist policies for the products that have future potential. The most striking examples can be found in policies implemented after the global financial crisis; especially, one can clearly trace these emphases in the recent British and US administrations discourses. After the 2008 economic crisis, 
the USA is the key country that has implemented protectionist policies mostly to shield their economy interest. It is understood that the new protectionist policies have gained more momentum with coming of the US President Donald Trump. The USA, Germany and Japan, which historically follow Great Britain, which is regarded as a 'role model' among developed countries, are the countries that implement such policies intensively. Today, many developed countries, which aim at increasing the power center in the global economy with the free-market argument, are implementing essentially protective policies in different ways. The developed countries, which eventually strengthen economically, can be the hottest supporters of protectionism, leaving their free-market advocacy for national interests.

The Trade Potential Restrictive Measures Report published by the European Commission at the beginning of September 2013 stated that the EU countries have taken special measures to limit trade 700 times since 2008, including, among others, 'limited access to information about the electricity market for foreign players' (European Commission Directorate-General for Trade, 2014) and that the tax imposed on import products on a global scale have increased significantly. In the period after the global financial crisis, an increasing level of protectionism stands out, especially in the G20 countries. A report published by the WTO highlights that between October 2015 and May 2016 the G20 countries took 145 new preventive measures. The average (October 2015-May 2016) of these new trade-restrictive measures is 21 per month, indicating that the G20 countries' economies have experienced the most significant increase since 2009 when the WTO was under the spotlight (WTO 2016). Thus, the trade barriers imposed by G20 countries are recorded as the highest monthly average protectionist trade measures observed after the global financial crisis. However, the report states that G20 countries removed only 387 of the 1,583 protection measures that came into effect after the crisis. The claims that affordable goods produced in China caused unfair competition in other countries' domestic markets and turn one of the most important reasons for the increasing protectionism. Many countries have implemented anti-dumping practices against the Chinese products with the claim of preventing unfair competition. The protective tendencies that emerged in the post-crisis period turned into the global trade war with the policies implemented by the US President Donald Trump in 2016. Since retaliation measures taken by the countries, targeted by the USA, have neutralized the World Trade Organization, there is no international institution to limit or referee this trend, and it is believed that an environment in which trade wars will be ignited further, the threshold will be exceeded and more radical measures will expand in the coming period. In conclusion, countries that have been strongly against protectionist policies in the past and struggled against protectionism at the WTO meetings have now tended to reverse towards protectionism. The fact that developed countries turn to protectionist policies harms world trade. While there is serious market shrinkage in world trade due to the crisis, the additional protectionist policies create a dangerous situation. 


\section{Discussion: The Acceleration of the US-China Trade War}

\section{Trump Administration's Internal Policies and the Confrontation between China and USA}

To understand the the US-China new version of the cold war and the internal policies of Trump's administration, we may start by the statement of Dieter Ernst, an economist and researcher, cited in the article by Junko Yoshida (2020), where Ernst argued that

there is no doubt that Commerce and USTR (US Trade Representative) should fight against unfair practices in IPR, trade secrets, and government procurement, wherever they occur, including in China. But most important, both the US government and the private sector need to join forces and develop and implement a national strategy to upgrade the country's innovation system in order to cope with the challenge of China's innovation policy from a position of strength ... in short, technology warfare based on crude techno-nationalism is threatening to destroy AI's global knowledge-sharing culture. This is true both for the 'America First' doctrine and for China's attempts to claim sovereignty over its cyberspace through the Great Firewall.

As the Donald Trump administration in the USA promised during the election period, Trump prioritized economic policies involving protectionism and mobilized trade wars in order to increase the workforce in the domestic market and at the same time stimulate American production and trade. Stating that the steel and aluminum industries are losing ground in the economy, the USA decided to set new tariffs and enforced regulations to strengthen these industries. In response to the US actions, China also mutually retaliated and decided on additional customs duties for many products (Shane 2018). During the last political campaigns in the USA, Trump criticized against Biden and frequently said 'China will own the United States' and that if Biden wins the Americans will 'have to learn to speak Chinese' (Xue and Chen 2020). Though Biden (2020) has different critics on China, as he argued in his Foreign Affairs article, 'to win the competition for the future against China or anyone else, the United States must sharpen its innovative edge and unite the economic might of democracies around the world to counter abusive economic practices and reduce inequality.'

However, the USA first decided to impose additional 25-percent tariffs on iron and steel imports and 10 per cent on aluminum imports on March 8, 2018 justifying this decision by the reason of the US national security and stating that it was in line with the protection rule of the World Trade Organization (White House 2018a; Swanson 2018). On April 3, 2018, the USA highlighted the issue of intellectual property, and stated that China made $\$ 300$ billion from the intellectual property theft from the US enterprises, as the former President Donald Trump said, 'we really have to look at access, forced technology transfer, and the theft of intellectual property, which just, by and of itself, is costing the United States and its companies at least $\$ 300$ billion a year' (White House 2017). Therefore, the United States have announced that it will impose a 25-percent customs duty on more than 1300 products of approximately $\$ 50$ billion imported from China (White House 2018b).

On the other hand, with the 'Made in China 2025' program, China plans to become the world leader in industries, including artificial intelligence, robotics, aircraft parts and high-speed trains. Following the US imposing an additional tax liability, on April 4, 
2018, China announced that it would impose a 25-percent customs duty on 106 items of mechanical and agricultural products such as commercial planes, automobiles, chemicals and soybeans, which amount to 50 billion dollars. Among these products, 'total 2019-20 U.S. soybean exports to China just above 16 million tonnes or 590 million bushels, up $20 \%$ on the year but down $56 \%$ from the 2016-17 record' (Braun 2019).

The trade wars that started in 2018 and continued to increase in 2019 have become more damaging in recent times and even have started the currency war in addition to the US trade war. As part of the US war on retaliation with China, there are increasing quotas, obstacles, measures and taxes. In this context, one of the increase decisions in the customs taxes took place in May 2019. The USA has increased the customs duty of 10 per cent to 200 billion dollars of Chinese products, even this phase was planned to rise to 25 per cent have been applied since June 2019. As a countermeasure, China declared that it imposed an additional customs duty of $\$ 60$ billion on the US goods, including sports equipment, musical instruments and wines, ranging from 5 to 25 per cent.

In August 2019, China decided to impose additional customs duties on the US products of $\$ 75$ billion, ranging from 5 to 10 per cent; the products covered by the decision include pork liver, marble, bicycle tire and sweet corn. Following this decision, the USA announced that it will apply a 30-percent tax on $\$ 250$ billion Chinese products, starting from October 2019. In addition to this, the USA announced that a 15-percent additional customs duty will be imposed on technological products such as shoes, clothing, residential textiles, laptops and mobile phones, starting from December 15, 2019. As of September 2019, the 15-percent customs duty has started to be imposed for 110 billion dollars of Chinese products (CBC 2019).

In addition to the ongoing trade wars, the United States have also started a fight for the dollar due to China's yuan depreciation, so the exchange rate war has become one of the agenda policies. The American central bank (FED), which had not been subject to interest cuts for eleven years, applied the interest cuts, the first at the July meeting and the second - at the September meeting. The resulting currency war is both the trigger and the result of the trade war, thus, making a kind of a vicious circle.

\section{The US-China Tech War}

The technological tension between the USA and China has been going on for a long time. Huawei had previously suffered from failing to inform officials before the takeover of American companies and patent infringements. However, the real escalation of this tension occurred in the first months of 2018 when the trade war between the USA and China became more prominent and spread to the technological field. While the year 2018 was accepted as the beginning of the technology cold war between Beijing and Washington, the year 2019 was marked by its deepening and expansion. The start was about a tit for tat over tariff between two powers. Still, in the current fight the USA and China found themselves engaged in a technology war over the global dominance of the Chinese telecom giant Huawei in the build-up of 5G network telecommunications (CNN 2019).

The main reason why the technology giant Huawei, which enables China to take an advantageous position in the global technological competition, has become the target, is the increasing power in the smartphone market as well as the power it has in the 5Gfield that is expected to revolutionize the world. The company is one of the most im- 
portant players in $5 \mathrm{G}$, which the world closely follows, and also Huawei holds more than 20 per cent of 5G standard-essential patents (Huawei 2019).

The new generation $5 \mathrm{G}$ mobile communication technologies would enable the formation of the 'Internet of Things (IoT)' which will fundamentally change daily life by linking smart cities and autonomous vehicles. At the center of these smart cities, which will be connected to each other, there will be the power that controls the $5 \mathrm{G}$ networks. Therefore, the main reason for the tension between the two great powers is not the rivalry in the smartphone market which turns it into a global technology battle, but the increasing influence of China to challenge America in 5G technology and artificial intelligence studies. America considers the rise of Huawei and hence of China as a threat because it has acquired intellectual property that will be effective in determining the future of $5 \mathrm{G}$ and also the new world order. Data gathering and processing and artificial intelligence rivalry, which seeks to maintain technical dominance as well as political and economic influence among the major powers, is gradually increasing. It is expected that 428 million devices will be integrated in 2025 in line with China's 'Made in China 2025' strategy (World Economic Forum 2018).

Previously, Huawei had problems with the American company's takeover process, as it did not notify the authorities and filed patent infringements. However, the immediate escalation of the tension took place in the first months of 2018, as the trade war between the USA and China became steadily apparent and leapt into the technological realm. In the 2012 report of the US House of Representatives' Intelligence Commission, Huawei was described as a 'national security threat.' As a justification, the report claimed that the technologies of the company could be used for spying by the Chinese Government (Holland 2019). The American authorities have raised national security concerns and, for several years, have rejected proposals from Chinese telecom operators accessing the US market. The Chinese companies started to be described as companies that spy on military and security services of the USA (Salinas 2018).

Although Washington has been pursuing the 'America First' policy, Beijing seeks to become the world's leading manufacturer and gain technical freedom through its 'Made in China 2025' policy. The USA is gradually increasing pressure on Chinese firms and takes new steps to disrupt this plan, which it considers as a vital risk for itself. However, some scholars, like Bremmer (2019) argue that development of a separate system of Chinese technology with its own standards, infrastructure, and supply chains is viewed as a significant geopolitical decision taken by China to compete with the West. The rising tech cold war is also addressed as 'the greatest threat to globalization since the end of World War II' and states a more worrisome threat than the military actions. The following Table 1 shows the chronology of the USA's actions and China's reactions on the trade disputes from April 2017 to May 2020. 
Table 1

\section{Chronology of Trade War between China and USA (Prepared by the Authors)}

\begin{tabular}{|c|c|c|}
\hline Time Period - General Context & US Actions & China's Reactions \\
\hline $\begin{array}{l}\text { April - May } 2017 \\
\text { Top-level negotiations to resolve } \\
\text { trade misbalances } \\
\text { 100-day plan for trade talks }\end{array}$ & $\begin{array}{l}\text { Investigation on steel and aluminum } \\
\text { imports is initiated. } \\
\text { The US allows China to sell cooked } \\
\text { poultry to the US }\end{array}$ & $\begin{array}{l}\text { US companies get greater access to } \\
\text { China's agriculture, energy, and } \\
\text { financial markets }\end{array}$ \\
\hline $\begin{array}{l}\text { February-April } 2018 \\
\text { Investigation into China's acts, } \\
\text { policies and practices relating to } \\
\text { technology transfer, intellectual } \\
\text { property and innovation. } \\
\text { The US initiates a WTO case } \\
\text { against China for discriminatory } \\
\text { licensing. } \\
\text { The US and China hold two rounds } \\
\text { of trade talks before tariffs are } \\
\text { cscalated again and the US relcases } \\
\text { the official statement (May 2018) }\end{array}$ & $\begin{array}{l}\text { Global safeguard tariffs: } \\
30 \% \text { on solar panels; } \\
20 \% \text { on washing machines (under } \\
\text { "safeguard" laws); } \\
25 \% \text { on steel imports; } \\
10 \% \text { on aluminum imports. (under } \\
\text { "Section } 232 \text { ") } \\
\text { High tech products \& Intellectual } \\
\text { Property Measures targeting China: } \\
\text { restricting investment in key technology } \\
\text { sectors; imposing import tariffs on } \\
\text { aerospace, IT, communication and } \\
\text { machinery; including ZTE in the Entity } \\
\text { List (Under "Section 301") }\end{array}$ & $\begin{array}{l}15-25 \% \text { tariffs on } 128 \text { product } \\
\text { categories including agricultural } \\
\text { commodities, fruit, wine, seamless } \\
\text { steel pipes, pork and recycled } \\
\text { aluminum. } \\
178.6 \% \text { antidumping duties on } \\
\text { sorghum imports from the US } \\
25 \% \text { tariff on } 106 \text { more products } \\
\text { including soybeans, autos, chemicals, } \\
\text { aircraft }\end{array}$ \\
\hline $\begin{array}{l}\text { June - July } 2018 \\
\text { Ongoing negotiations; internal } \\
\text { discussion of the new lists of } \\
\text { restrictions }\end{array}$ & $\begin{array}{l}\text { implements first China-specific tariffs: } \\
25 \% \text { tariff on } 818 \text { products (imports worth } \\
\text { \$34 billion) ("list 1") }\end{array}$ & $\begin{array}{l}25 \% \text { tariff on } 545 \text { products (imports } \\
\text { worth } \$ 34 \text { billion), including } \\
\text { agricultural products, autos and aquatic } \\
\text { products }\end{array}$ \\
\hline $\begin{array}{l}\text { August } 2018 \\
\text { The partics exchange preliminary } \\
\text { lists. } \\
\text { China secks WTO authorization to } \\
\text { impose } \$ 7 \text { billion in tariffs }\end{array}$ & $\begin{array}{l}25 \% \text { tariff on } 284 \text { goods (worth } \$ 16 \\
\text { billion) including: semiconductors, } \\
\text { chemicals, plastics, motorbikes and } \\
\text { clectric scooters ("list 2") }\end{array}$ & $\begin{array}{l}\text { proposes a range of additional tariffs } \\
\text { on } 5,207 \text { products originating from the } \\
\text { US (worth US\$ } 60 \text { billion. } \\
25 \% \text { tariffs on } 333 \text { goods (imports } \\
\text { worth } \$ 16 \text { billion) including: coal, } \\
\text { copper scrap, fuel, buses }\end{array}$ \\
\hline $\begin{array}{l}\text { September } 2018 \\
\text { China cancels the trade } \\
\text { negotiations and releases the White } \\
\text { Paper stating the official position }\end{array}$ & $\begin{array}{l}10 \% \text { tariff (announced subject to further } \\
\text { increase up to } 25 \% \text { in } 2019 \text { ) on } \$ 200 \\
\text { billion worth imports from China ("list } \\
3 " \text { ) }\end{array}$ & $\begin{array}{l}\text { Implements } 5 \% \text { and } 10 \% \text { tariffs on } \$ 60 \\
\text { billion worth imports }\end{array}$ \\
\hline $\begin{array}{l}\text { November - December } 2018 \\
\text { US and China resume trade talks } \\
\text { G20 summit in Buenos Aires. } \\
\text { The US and China agree to } \\
\text { temporary truce (not to increase } \\
\text { tariffs for } 90 \text { days) }\end{array}$ & $\begin{array}{l}\text { The US announces that the new list of } \\
\text { tariffs will be delayed } \\
\text { Also issues an update to the "Section } 301 \text { " } \\
\text { report on China's intellectual property } \\
\text { violations. }\end{array}$ & $\begin{array}{l}\text { Provides an undisclosed list of } 142 \\
\text { actions it would take to resolve the } \\
\text { trade war } \\
\text { China increases import of agricultural } \\
\text { and energy products, lowers tariffs on } \\
\text { cars and auto products from } 25 \% \text { to } \\
\text { standard } 15 \% \\
\text { lowers tariffs on US autos; resumes } \\
\text { buying US soybcan exports }\end{array}$ \\
\hline $\begin{array}{l}\text { January - April } 2019 \\
\text { Ongoing trade negotiations both in } \\
\text { Beijing and Washington } \\
\text { US and China agree to establish } \\
\text { trade deal enforcement offices. }\end{array}$ & $\begin{array}{l}\text { Trump announces that he will extend the } \\
\text { March } 1 \text { trade deal truce deadline. }\end{array}$ & $\begin{array}{l}\text { China extends the suspension of } \\
\text { additional tariffs on US autos and auto } \\
\text { parts } \\
\text { bans all types of fentanyl. }\end{array}$ \\
\hline $\begin{array}{l}\text { May - June } 2019 \\
\text { Ongoing trade negotiations before } \\
\text { the G20 summit }\end{array}$ & $\begin{array}{l}25 \% \text { tariff (increase from } 10 \% \text { ) with } \\
\text { another } \$ 325 \text { billion } \\
\text { Huawei and five other companies of } \\
\text { China are added to the "Entity List" }\end{array}$ & $\begin{array}{l}\text { Tariffs rates on S60 billion worth of } \\
\text { US exports, tariffs increases range } \\
\text { from } 5 \% \text { to } 25 \%\end{array}$ \\
\hline $\begin{array}{l}\text { June } 2019 \\
\text { G20 summit in Osaka. } \\
\text { The parties agree to avoid } \\
\text { increasing tariffs }\end{array}$ & $\begin{array}{l}\text { The ban on deals with Huawei is } \\
\text { reconsidered. } \\
110 \text { products are excluded from the } 25 \% \text { - } \\
\text { tariffs }\end{array}$ & $\begin{array}{l}\text { China issues white paper on US-China } \\
\text { economic relations. } \\
\text { announces its plans to increase import } \\
\text { of agricultural products }\end{array}$ \\
\hline $\begin{array}{l}\text { July - August } 2019 \\
\text { Shanghai Talks fail } \\
\text { US Treasury declares China is a } \\
\text { currency manipulator. }\end{array}$ & $\begin{array}{l}\text { announces plans to impose a } 10 \% \text { tariffs } \\
\text { on USS300 billion of Chinese goods like } \\
\text { clothing and electronics from September } \\
\text { 1("list 4") } \\
\text { US announces new tariffs in } 2 \text { waves. }\end{array}$ & $\begin{array}{l}\text { China announces tariffs of } 5 \text { and } 10 \% \\
\text { on USS75 billion of US goods from } \\
\text { September } 1 \text { and December } 15 . \\
\text { China also confirms it will reinstate } \\
\text { tariffs on US cars and car parts from } \\
\text { December } 15 \text {. }\end{array}$ \\
\hline $\begin{array}{l}\text { September- October2019 } \\
\text { Mid-level trade talks in } \\
\text { Washington(13th round of trade } \\
\text { talks) }\end{array}$ & $\begin{array}{l}\text { US tariffs on more than USS } 125 \text { billion } \\
\text { worth of Chinese imports begins } \\
\text { Donald Trump agrees to delay new tariffs } \\
\text { on USS } 250 \text { billion worth of Chinese } \\
\text { goods from October } 1 \text { to October } 15 \text { as a } \\
\text { good will gesture to avoid the } 70 \text { th } \\
\text { anniversary of the People's Republic of } \\
\text { China }\end{array}$ & $\begin{array}{l}\text { China announces that it will offer } \\
\text { exemptions to } 16 \text { types of US imports } \\
\text { from additional tariffs (include } \\
\text { products such as pesticides, animal } \\
\text { feeds, lubricants, and cancer drugs) } \\
\text { China unveils tariff exemption list for } \\
\text { US imports(including soybeans, pork, } \\
\text { and other farm goods) }\end{array}$ \\
\hline
\end{tabular}




\begin{tabular}{|c|c|c|}
\hline $\begin{array}{l}\text { October-November } 2019 \\
\text { Trade talks over phonc, agrec on } \\
\text { trade points "in principle" }\end{array}$ & $\begin{array}{l}\text { US announces "Phase 1" deal, delays } \\
\text { tariff increase for Chincse goods } \\
\text { US tariff exclusion process for US\$300 } \\
\text { billion of Chinese imports. } \\
\text { US releases new regulatory guidelines for } \\
\text { its telecom networks procedure to protect } \\
\text { telecom networks from national security } \\
\text { threats }\end{array}$ & $\begin{array}{l}\text { China wins WTO case, able to } \\
\text { sanction US } \$ 3.6 \text { billion worth US } \\
\text { imports }\end{array}$ \\
\hline $\begin{array}{l}\text { December } 2019 \\
\text { China and the US agree to "phase } \\
\text { one trade deal" days before a } 15 \% \\
\text { tariff was set to be imposed on } \\
\text { around US\$160 billion of Chinese } \\
\text { goods. }\end{array}$ & $\begin{array}{l}\text { US agree to reduce tariffs on US\$120 } \\
\text { billion of Chinese goods imposed in } \\
\text { September. }\end{array}$ & $\begin{array}{l}\text { China suspended tariffs on second set } \\
\text { of US goods also due to come into } \\
\text { force on December } 15\end{array}$ \\
\hline $\begin{array}{l}\text { January } 2020 \\
\text { China and the US sign "Phase one" } \\
\text { of the Economic and Trade } \\
\text { Aggrement. } \\
\text { Implementation is expected within } \\
60 \text { days of signing. }\end{array}$ & $\begin{array}{l}\text { The deal results in the suspension of a } \\
\text { planned December tariff on around } \\
\text { US\$162 billion in Chinese goods, with an } \\
\text { cxisting } 15 \text { per cent duty on imports worth } \\
\text { around US\$110 billion halved }\end{array}$ & $\begin{array}{l}\text { China agree to buy an additional } \\
\text { US } \$ 200 \text { billion of American goods and } \\
\text { services over the next two years. }\end{array}$ \\
\hline $\begin{array}{l}\text { February } 2020 \\
\text { China announces new tariff } \\
\text { exemptions for US imports }\end{array}$ & & $\begin{array}{l}\text { China halves additional tariffs on } \\
\text { US\$ } 75 \text { billion of products imposed in } \\
2019 \text {, including automotive and } \\
\text { agricultural goods like pork, chicken, } \\
\text { beef and soybeans, chemicals, crude } \\
\text { oil, whiskey, and seafood. } \\
\text { grants } 696 \text { US commodities will be } \\
\text { exempted from Chinese additional } \\
\text { tariffs. }\end{array}$ \\
\hline $\begin{array}{l}\text { May } 2020 \\
\text { China-US reaffirm their phase one } \\
\text { trade deal commitments over the } \\
\text { phone }\end{array}$ & $\begin{array}{l}\text { the two Trump cabinet officials said in a } \\
\text { joint statement that both sides "agreed that } \\
\text { in spite of the current global health } \\
\text { cmergency, both countrics fully expect to } \\
\text { meet their obligations under the } \\
\text { agreement in a timely manner." }\end{array}$ & $\begin{array}{l}\text { China announces a second batch of } \\
\text { trade war tariff exemptions covering } \\
79 \text { goods, including ores, chemicals } \\
\text { and certain medical products } \\
\text { China allows imports of barley and } \\
\text { blueberries from the US }\end{array}$ \\
\hline Total & $\begin{array}{l}\text { US tariffs applied exclusively to } \\
\text { Chinese goods: } \\
\text { US\$550 billion }\end{array}$ & $\begin{array}{l}\text { Chinese tariffs applied exclusively to } \\
\text { US goods: } \\
\text { US\$ } 185 \text { billion }\end{array}$ \\
\hline June 2020 & $\begin{array}{l}\text { The US Department of Commerce } \\
\text { announces technology not normally } \\
\text { subject to export controls can be } \\
\text { disclosed to Huawei for the purpose of } \\
\text { developing international standards in } \\
\text { sectors such as } 5 \mathrm{G} \text { networks. }\end{array}$ & \\
\hline July 2020 & $\begin{array}{l}\text { US seeks public comments to exclude } \\
\text { Chinese imports from Section } 301 \text { tariffs. } \\
\text { The Office of the US Trade } \\
\text { Representative (USTR) has announced } 37 \\
\text { exemption lists, which excluded specific } \\
\text { Chinese imports from US additional } \\
\text { tariffs. }\end{array}$ & $\begin{array}{l}\text { US Department of Agriculture } \\
\text { announced that China booked its } \\
\text { biggest single-day US corn purchase } \\
\text { buying } 1.762 \text { million tonnes and also } \\
\text { booked deals to buy } 129,000 \text { tons of } \\
\text { soybeans. }\end{array}$ \\
\hline $\begin{array}{l}\text { August } 2020 \\
\text { The US and China postponed the } \\
\text { review of their phase one trade deal. } \\
\text { The two sides agreed to create } \\
\text { conditions and atmosphere to } \\
\text { continue pushing forward the } \\
\text { implementation of the US-China } \\
\text { phase one trade agreement. }\end{array}$ & $\begin{array}{l}\text { The office of the US Trade } \\
\text { Representative did not respond to queries } \\
\text { about plans to review the trade deal. } \\
\text { US suspends reciprocal tax exemption on } \\
\text { Hong Kong shipping firms. }\end{array}$ & $\begin{array}{l}\text { China says trade deal review to be } \\
\text { rescheduled. }\end{array}$ \\
\hline Total & $\begin{array}{l}\text { US tariffs applied exclusively to } \\
\text { Chinese goods: US } \$ 550 \text { billion }\end{array}$ & $\begin{array}{l}\text { Chinese tariffs applied exclusively } \\
\text { to US goods: US } \$ 185 \text { billion }\end{array}$ \\
\hline
\end{tabular}

Source: Wong and Koty 2020; Yoshida 2020. 


\section{The Polarized World in the New Cold War}

Although Chinese companies have made millions of dollars in the USA to increase their investments and customer portfolio, the process has been reversed by increasing customs duties and applying additional sanctions following Donald Trump's election as president. In addition, as of the end of 2018, Trump's efforts to block companies have crossed American borders. The antagonism was internationalized when Trump called for support from Australia, Canada, South Korea and offered financial assistance to the EU countries that wanted to join the embargo against the threat of espionage using China's Huawei networks in countries with the US military bases (Woo and O'Keeffe 2018).

The political pressure of the US government emphasizes that doing business with Chinese telecom companies is a 'national security problem.' This makes it difficult for Chinese companies to struggle for a share of the US market for a long time. In addition to the government, six US intelligence agencies, including the CIA, FBI, and NSA, have warned the public against the espionage of Huawei and ZTE to prevent the use of Chinese companies' products and services. Besides, Pentagon banned the sale of Huawei and ZTE phones at military bases on the grounds of 'potential security threats' (Paganini 2018).

Anti-Huawei parties claim that this company-led network will lead to new cyber security vulnerabilities. The fact that Ren Zhengfei, the founder and chief executive officer of the company, served in the military before establishing the company and its relationship with the Communist Party is seen as a threat to the national security of other countries. It is stated that with the help of the technologies developed by the company, it will engage in espionage activities related to foreign governments. In addition, Huawei's current competitors, American Cisco, Finnish Nokia, and Swedish Ericsson, are struggling against the company's record-breaking global sales. They deal with Huawei as a common threat to address these challenges and boycott the company in every possible way in many areas where the company stands out (Marek 2019).

In the final stage of the US struggle against the Chinese telecommunications industry, Five Eyes has shared a common attitude: Australia and New Zealand have decided to ban Huawei from their country's 5G infrastructure building process, and the British IT Group has decided not to use existing Huawei equipment from the center of the communications infrastructure in many areas. In addition to these decisions, the French Telecom company Orange declared not to work with Huawei in the 5G installation, German Deutche Telecom has stated that they are concerned about Huawei's security vulnerability, and decided to ban new generation mobile networks; Taiwan's decision to ban the use of Huawei and ZTE's network infrastructure and equipment for five years also was added.

As a result of this competition, the countries have to choose between the Chinese or US suppliers for the next generation of 5G wireless technology. In the process, which may be called the new cold war period, the US administration is lobbying to prevent the purchase of mobile and infrastructure equipment from Huawei, arguing that the company could secretly carry out espionage activities for the Chinese government. European countries expressed concern that China could expand the scope of its intelligence activities by accessing mobile and other communications networks through the next generation of $5 \mathrm{G}$ technology. Huawei's growing power in the IT sector is leading anti-Huawei countries, especially the USA, to preventive policies in which they take more precautionary measures to avoid lagging behind in the technological race. The Chinese experts 
emphasize that European countries have learned lessons from history by linking boycott and sanction decisions with the Opium Wars (Wiseman and Bajak 2018).

It is mentioned in the report issued by the American National Security Council that China poses a serious threat to the information security and economic stability of the United States. It is analyzed in the study that information has become the twenty-firstcentury oil, and the way to achieve progress in the field of information and communication is to establish a safe $5 \mathrm{G}$ network around the world. It is also reported that China has built the most extensive data system in the world, and if the USA fails to develop a 5G network, it will inevitably lose its dominance over China (Kheel and Mitchell 2018).

The size of global 5G network shows that the US-China trade war is not just about customs duties, iron, and steel, automobiles, or soy. This condition points to the emergence of next age technologies in the twenty-first century and, thus, to the global rivalry between the two countries in which state the economic, intelligence and military power would rule. The competition between the US-led Western world and China stands out as a technology battle, which is the twenty-first-century oil and technological dominance with it.

At the last stage, mutual diplomatic initiatives, the reactions of the international community and arrests of former diplomats, businessmen and citizens are indicative of the tension between the two powers which is getting out of control. It is an undeniable fact that what happened between the USA and China will lead to lasting damage to the future of bilateral relations as the beginning of a new cold war. Though 'in every context, more cooperation rather than less is the best way to arrive at an unparalleled solution' (Islam 2020a). Table 2 shows the future relations and confrontations between China and USA and the trade and tech war under the auspicious of new cold war in three theoretical frameworks such as liberals, realists and constructivists; however, this idea has been previously argued, developed and discussed by Aaron L. Friedberg (2005) in his article on 'the Future of U.S.-China Relations: Is Conflict Inevitable?'

Table 2

The Future Peaceful and Conflicting Trade Relations between USA and China

\begin{tabular}{|c|c|c|}
\hline Theorists & Peaceful Trade Relations & Conflicting Trade Relations \\
\hline \multirow{3}{*}{ Liberals } & Interdependence Trade Relations & $\begin{array}{l}\text { As China's Administration: } \\
\text { Authoritarian Trade Policy }\end{array}$ \\
\hline & Institutions & \begin{tabular}{|l|} 
The Threats of Institutional \\
Change between Two Countries
\end{tabular} \\
\hline & Democratization & $\begin{array}{l}\text { The USA current and Future Admin- } \\
\text { istration: A Crusading Democracy, } \\
\text { and Interactive Effects such as } \\
\text { Trump's Administration }\end{array}$ \\
\hline \multirow{3}{*}{ Realists } & China's Trade Expansion: Limited & China's Trade Relations: Rising \\
\hline & $\begin{array}{l}\text { China's Global Trade Policy Aims: } \\
\text { Constrained }\end{array}$ & $\begin{array}{l}\text { China's Global Trade Policy Aims: } \\
\text { Expanding }\end{array}$ \\
\hline & $\begin{array}{l}\text { Security Dilemma of Both Countries: } \\
\text { Muted }\end{array}$ & $\begin{array}{l}\text { Security Dilemma of Both Countries: } \\
\text { Intense }\end{array}$ \\
\hline Constructivists & $\begin{array}{l}\text { Identities, Strategic Cultures, Norms } \\
\text { Related to Trade: Flexible and 'Sof- } \\
\text { tening' via Institutional Contact be- } \\
\text { tween the Two Courtiers }\end{array}$ & $\begin{array}{l}\text { Inflexible and 'Hardening' via Shocks } \\
\text { and Disputes, as like Huawei Crisis }\end{array}$ \\
\hline
\end{tabular}

Source: Friedberg 2005. 


\section{Conclusion}

While the Washington follows 'America First' and 'Make America Great Again' strategy, Beijing's 'Made in China 2025' strategy aims at becoming the world's production leader and achieving technological independence. In order to disrupt this plan, which it sees as a vital risk for itself, the USA is gradually increasing pressure on the Chinese Huawei and ZTE companies and taking new measures in this direction. These two strategies can be seen as heralding the new cold war in the field of advanced technology. This undeclared war between the US-led Western world and China stands out as a struggle over data, which is the oil of the twenty-first century, and also over winning technological superiority. Therefore, it is possible to describe this new phenomenon as the period of 'New Cold War'. This points to the global competition between the two actors: which state will dominate in the twenty-first century in the emerging generation of technology, and hence obtain the economic, intelligence and military power.

Trade wars, as the history of the world economy shows, have no winners. Both sides suffer defeats, but the USA has had a long record of winning trade agreements and getting other countries to stand back. China has also demonstrated its ability to negotiate, raising bilateral trade imbalances to USD 200 billion, and liberalized its domestic market for the US firms. However, the requirements and sanctions imposed by the USA have a substantial impact on China's industrial policy and are threatening the 'Made in China 2025' plan. The foregoing suggests that the PRC will likely gain leadership in ten high-tech technologies (robotics, artificial intelligence, etc.). The USA is convinced that China's first gains in executing the program derive from the use of American technology and would continue to limit the Chinese industry's access to them. Trade Wars, which cover a long time since 2018, have not been resolved ultimately between the two countries. In order to solve the problem, more effective diplomacy and joint decisions between Beijing and Washington should be implemented. Even though what happened between the two countries during this period is not in an economic context, it tends to be zero-sum in the decision-making process.

The geopolitical rivalry between the major powers has been increasing for many years. In the 'Post-Cold War' and 'New Cold War' era and after the COVID-19, though globalization has committed the world to a win-win system, the actors have started to return to zero-sum games when they prioritize their own interests, as it can be seen clearly in the countries' foreign policy priorities and competitiveness.

\section{REFERENCES}

Acharya, A., and Buzan, B. 2007. Why is There no non-Western International Relations Theory? An Introduction. International Relations of the Asia-Pacific 7: 287-312. Doi: 10.1093/irap/lcm012.

Acharya, A., and Buzan, B. (eds.) 2010. Non-Western International Relations Theory: Perspectives on and beyond Asia. New York: Routledge.

Ari, T. 2013. Uluslararası Ilişskiler ve Dış Politika (International Relations and Foreign Policy). 10. Basım, MKM Yayıncılık, Bursa.

Aron, R. 1972. Etudes politiques. Paris, France: Gallimard.

Aron, R. 1976. Penser la guerre, Clausewitz. Vol. 2, L'age planetaire. Paris, France: Gallimard. 
Aron, R. 1983. Memoires. Paris: Julliard.

Biden, J. R. 2020. Why America Must Lead Again: Rescuing U.S. Foreign Policy after Trump. Foreign Affairs, March/April. URL: https://www.foreignaffairs.com/articles/ united-states/2020-01-23/why-america-must-lead-again. Accessed October 29, 2020.

Blas, J. 2020. Donald Trump's Oil Deal: The Inside Story of How the Price War Ended. Bloomberg News, April 13. URL: https://o.canada.com/commodities/energy/trump-oilprice-deal-inside-story/wcm/47ec8921-93df-4517-a770-92d1c1841aa4. Accessed October 30, 2020.

Bouët, A. 2018. Les guerres commerciales sont-elles bonnes et faciles à gagner? [online], URL: http://parisinnovationreview.com/article/les-guerres-commerciales-sont-elles-bonneset-faciles-a-gagner.

Bremmer, I. 2019. The End of the American Order: Ian Bremmer speech at 2019 GZERO Summit. Eurasia Group, November 18. URL: https://www.eurasiagroup.net/livepost/end-of-american-order-ian-bremmer-2019-gzero-summit-speech.

Bown, Ch. P., and Kolb, M. 2020. Trump's Trade War Timeline: An Up-to-Date Guide. Peterson Institute for International Economics. URL: https://www.piie.com/blogs/tradeinvestment-policy-watch/trump-trade-war-china-date-guide.

Braun, K. 2019. China Still Dominates U.S. Soybean Exports despite Trade War. Reuters, April 18. URL: https://uk.reuters.com/article/us-usa-soybeans-braun-idUKKCN1RU0R8. Accessed October 27, 2020.

Buzan, B., and Cox, M. 2013. China and the US: Comparable Cases of 'Peaceful Rise?' The Chinese Journal of International Politics 6 (2): 109-32.

Campbell, S. L. 1989. Raymond Aron: The Making of a Cold Warrior. The Historian, 51 (4): 551-573.

Carnegie, A. 2018. Trump's Trade War Escalates. Foreign Affairs, June 25. URL: https://www.foreignaffairs.com/articles/2018-06-25/trumps-trade-war-escalates.

CBC. 2019. Trump's $15 \%$ tariffs on $\$ 112 \mathrm{~B}$ in Chinese goods take effect. $C B C . c a$, September 2. URL: https://www.cbc.ca/news/business/trump-tariffs-chinese-import-take-effect1.5267234\#: :text=The $\% 2015 \% 20$ per $\% 20$ cent $\% 20$ U.S.,earlier\%20rounds\%20of\%20tari ff\%20increases. Accessed October 27, 2020.

CBS News. 2018. Huawei CFO Arrest: Meng Wanzhou Faces Fraud Charges, Extradition. CBS News, December 7. URL: https://www.cbsnews.com/news/huawei-cfo-arrest-mengwanzhou-faces-us-fraud-charges-and-extradition/. Accessed on 18 May 2020.

Chin, G., and Thakur, R. 2010. Will China Change the Rules of Global Order? The Washington Quarterly 33 (4): 119-138.

Chunding, L., Chuantian, H., and Chuangwei, L. 2018. Economic Impacts of the Possible China-US Trade War. Emerging Markets Finance and Trade 54 (7): 1557-1577.

CNN. 2019. https://edition.cnn.com/2019/02/14/tech/huawei-nokia-ericsson-5g/index.html

Dadak, C. 2010. A 'New Cold War'? The Independent Review 15 (1): 89-107.

Demir, N., Tekir, O. 2018 Marshall Planı, Yeni İpek Yolu Projesi ve Çin - ABD Rekabeti. İönü University International Journal of Social Sciences 7 (1): 32-45.

European Commission Directorate-General for Trade. 2014. 11th Report on Potentially Trade-Restrictive Measures Identified in the Context of the Financial and Economic Crisis. URL: https://trade.ec.europa.eu/doclib/docs/2014/november/tradoc_152872.pdf. 
Ferguson, N. 2019. The New Cold War? It's with China, and It has already Begun? New York Times, December 2. URL: https://www.nytimes.com/2019/12/02/opinion/chinacold-war.html. Accessed October 20, 2020.

Freedman, L. 2019. The Rise and Fall of Great Power Wars. International Affairs 95 (1): $101-18$.

Friedberg, A. L. 2005. The Future of U.S.-China Relations: Is Conflict Inevitable? International Security 30 (2): 7-45.

Global Trade Alert. 2018. The GTA Reports. URL: https://www.globaltradealert.org/reports. Accessed October 5, 2020.

Grossman, G. M., and Helpman, E. 1995. Trade Wars and Trade Talks. Journal of Political Economy 103 (4): 675-708.

Herman, E. S., and Chomsky, N. 1988. Manufacturing Consent: The Political Economy of the Mass Media. Pantheon.

Hoffmann, S. 1985. Raymond Aron and the Theory of International Relations. International Studies Quarterly, 29 (1): 13-27. https://doi.org/10.2307/2600476.

Holland, S. 2019. U.S. President Trump does not Want to do Business with China's Huawei. Reuters. URL: https://ru.reuters.com/article/internetNews/idUKKCN1V80P6. Accessed on 25 May 2020.

Hove, M. 2016. The Emergence of the New Cold War: The Syrian and Ukraine Conflicts. Jadavpur Journal of International Relations 20 (2): 135-156. Doi:10.1177/0973598416 680432

Hove, M., and Mutanda, D. 2015. The Syrian Conflict 2011 to the Present: Challenges and Prospects. Journal of Asian and African Studies 50 (5): 559-570.

Huawei. 2019. Respecting and Protecting Intellectual Property: The Foundation of Innovation. Huawei White Paper on Innovation and Intellectual Property, June 27. URL: https://www-file.huawei.com/-/media/CORPORATE/PDF/white\%20paper/2019/Huawei White_Paper_on_Innovation_and_Intellectual_Property.pdf

Hudson V. M. and Day B. S. Day. 2020. "Foreign Policy Analysis, Classic and Contemporary Theory", Rowman and Littlefield; New York.

Hughes N. C. 2005. A Trade War with China? Foreign Affairs 84 (4): 94-106. URL: https://www.jstor.org/stable/20034423.

Ikenberry, J. G. 2008. The Rise of China: Power, Institutions, and the Western Order. In Ross, R. S., and Zhu Feng (eds.), China's Ascent: Power, Security, and the Future of International Politics (pp. 89-114). New York: Cornell University Press.

Ikenberry, J. G. 2011. The Future of the Liberal World Order: Internationalism After America. Foreign Affairs, May/June, 2011.

Islam, M. N. 2019a. Emerging Global Organizations and Groups: A Paradigms Shift for New World Order. ADAM AKADEMI Sosyal Bilimler Dergisi 9 (2): 471-490. DOI: 10.31679/adamakademi.508998.

Islam, M. N. 2019b. Güç, strateji ve potansiyeller: Çin ordusunun temel yetenekleri ve unsurları üzerine bir inceleme [Power, strategy and potentials: A study on the factors and key capabilities of China's military]. Cappadocia Journal of Area Studies (CJAS) 1 (1): $100-110$ 
Islam, M. N. 2020a. Rethinking Turkey-Iraq Relations: The Dilemma of Partial Cooperation. Insight Turkey 22 (1): 257-260.

Islam, M. N. 2020b. Turkey, Asia Anew and South Asia: A Comparative Assessment on Bilateral Relations and Soft Power Policy with Bangladesh, India, and Pakistan. TU RAN-SAM Uluslararası Bilimsel Hakemli Dergisi 12 (47): 379-398. Doi: 10.15189/ 1308-8041.

Islam, M. N., and Cansu, E. E. 2020. BRI, CPEC, and Pakistan: A Qualitative Content Analysis on China's Grand Strategies. International Journal on World Peace 37 (3): 35-64.

Ivaniš, Ž., Đorđević, I. L., and Jeftić, Z. 2016. A New Cold War or Continuation of the Old One. Vojno delo 68 (4): 36-45.

Jakóbowski, J. 2018. The US-China Trade Dispute: Phase Two. (A. Eberhardt, K. Kazimierska, and M. Zarębska, Dü). OSW Commentary Centre for Eastern Studies 276: 1-6.

Kaplan, R. D. 2019. A New Cold War Has Begun. Foreign Policy, January 7. URL: https://foreignpolicy.com/2019/01/07/a-new-cold-war-has-begun/. Accessed October 26, 2020 .

Keller, W. W., and Rawski, Th. G. 2007. China's Rise and the Balance of Influence in Asia (The Security Continuum). Pittsburg: University of Pittsburgh Press.

Kheel, R., and Mitchell, E. 2018. Pentagon Fears Losing Race for 5G to China. The Hill, September 25. URL: https://thehill.com/policy/defense/408181-pentagon-fears-losingrace-for-5g-to-china. Accessed October 15, 2020.

Kubalkova, V., and Cruickshank, A. A. 1986. The 'New Cold War' in 'Critical International Relations Studies'. Review of International Studies 12 (3): 163-185.

Layne, Ch. 2020. Preventing the China-U.S. Cold War from Turning Hot. The Chinese Journal of International Politics 13 (3): 343-385. DOI: https://doi.org/10.1093/cjip/poaa012.

Liu, L. 2006. Quality of Life as a Social Representation in China: A Qualitative Study. Soc Indic Res 75: 217-240. https://doi.org/10.1007/s11205-004-3198-Z.

Manish, K. P., and Krishnan, S. S. 2018. Trade War-An Overview. International Journal of Trend in Scientific Research and Development 2 (6): 8-15.

Marek, S. 2019. Huawei's 5G RAN Portfolio Beats Ericsson, Nokia and Others, Report Says. URL: https://www.fiercewireless.com/wireless/huawei-s-5g-ran-portfolio-beatsericsson-nokia-and-others-report-says. Accessed on $5^{\text {th }}$ April 2020.

Mearsheimer, J. J. 2006. China's Unpeaceful Rise. Current History 105 (690): 160-62.

Mearsheimer, J. 2010. The Gathering Storm: China's Challenge to US Power in Asia, The Chinese Journal of International Politics 3: 381-396.

Mearsheimer, J. H. 2001. The Tragedy of Great Power Politics. New York, NY: W.W. Norton.

Meltzer, J. P., and Shenai, N. 2019. The US-China Economic Relationship - A Comprehensive Approach. Brookings-Quality, February 28. URL: https://www.brookings.edu/ research/the-us-china-economic-relationship-a-comprehensive-approach/.

Moisi, D. 2018. Dans le monde de Trump et Poutine, le pire devient possible. LesEchos, March 22. URL: https://www.lesechos.fr/2018/03/dans-le-monde-de-trump-et-poutinele-pire-devient-possible-987297.

Nyadera, I. N., and Islam, Md N. 2020a. Transnational Operations, International Reactions, and Legitimacy: The Case of Turkey and Saudi Arabia. Contemporary Review of the Middle East 7 (3): 317-338. DOI: https://doi.org/10.1177/2347798920921965. 
Nyadera, I. N., and Islam, Md N. 2020. Link Between Administration, Politics, and Bureaucracy. In Farazmand, A. (ed.), Global Encyclopedia of Public Administration, Public Policy, and Governance. Springer, Cham. DOI: 10.1007/978-3-319-31816-5_3903-1.

Olanrewaju, F., and Joshua, S. 2015. The Diplomatic Dimensions of the Syrian Conflict. Jadavpur Journal of International Relations 19 (1): 43-63.

Paganini, P. 2018. The Pentagon Bans Huawei and ZTE phones from Stores on Military Bases. URL: https://securityaffairs.co/wordpress/72163/intelligence/huawei-zte-ban.html Accessed on 5 November 2019.

Wiseman, P., and Bajak, F. 2018. Why Huawei Arrest Deepens Conflict between US and China? AP News, December 7. URL: https://apnews.com/article/9e8bb187c6fb475 48f35a297b81da9aa. Accessed October 26, 2020.

Piachaud, J. 2008. A New Cold War or the Continuation of the Old? Medicine, Conflict and Survival 24 (4): 253-254. DOI: 10.1080/13623690802489458.

Rachman, G. 2020. A New Cold War: Trump, Xi and the escalating US-China confrontation. Financial Times, October 5. URL: https://www.ft.com/content/7b809c6a-f73346f5-a312-9152aed28172. Accessed October 25, 2020.

Rose, G. 1998. Neoclassical Realism and Theories of Foreign Policy. World Politics 51 (1): $144-172$.

Sadri, H. A., and Burns, N. L. 2010. The Georgia Crisis: A New Cold War on the Horizon? Caucasian Review of International Affairs 4 (2): 126-144.

Salinas, S. 2018. Six Top US Intelligence Chiefs Caution against Buying Huawei Phones. $C N B C$, February 13. URL: https://www.cnbc.com/2018/02/13/chinas-hauwei-top-usintelligence-chiefs-caution-americans-away.html. Accessed on 20 May 2020.

Sardana, M. M. K. 2018. Causes and Consequences of the Escalating Trade War between the US and China. ISID (Institute for Studies in Industrial Development) Discussion Note, 5 (July). URL: http://103.82.220.134/pdf/DN1805.pdf.

Say, S. 2012. İbn Haldun'un Düşünce Sistemi ve Uluslararası İlişkiler Kuramı. İstanbul: İlk Harf Yayınları.

Savinov, Y. A., Zelenuk, A. N., Taranovskaja, E. V., Orlova, G. A., and Skurova, A. V. 2019. Increased Protectionism in US Trade Policy. Russian Foreign Economic Bulletin $1: 36-51$.

Shane, D. 2018. China Fires Back, Announcing Tariffs on US Planes, Cars and Soybeans. CNN, Business, April 4. URL: https://money.cnn.com/2018/04/04/news/economy/ chinatariffs-us-goods-soybeans/.

Sheikh, R. S. 2018. Les États-Unis ne pourront pas gagner la guerre commerciale contre la Chine [online] URL: https://www.mondialisation.ca/les-etats-unis-ne-pourront-pasgagner-la-guerre-commerciale-contre-la-chine/5626497.

Shambaugh, J. 2004. The Effect of Fixed Exchange Rates on Monetary Policy. The Quarterly Journal of Economics 119 (1): 301-352.

Sirby, K., and Arunachhalam, P. 2018. The US-China Trade Competition: An Overview. Munich Personal RePEc, June 9. URL: https://mpra.ub.unimuenchen.de/87236/1/MPRA paper_87236.pdf

Sinitsyn, I., and Kuimov, P. 2018. The Economic Terrorism of the USA with Regard to Europe, Russia and Other Countries. Vlast 9: 236-241. 
Sune, E. 2016. Non-Western International Relations Theory and Ibn Khaldun. All Azimuth 5 (1): 79-88.

Sun, H. 2019. U.S.-China Tech War Impacts and Prospects. China Quarterly of International Strategic Studies 5 (2): 197-212. DOI https://doi.org/10.1142/S237774001950012X.

Suisheng, Z., Guo, D. 2019. A New Cold War? Causes and Future of the Emerging USChina Rivalry. Vestnik RUDN. International Relations 19 1: 9-21.

Swanson, A. 2018. Trump to Impose Sweeping Steel and Aluminum Tariffs. The New York Times, March 1, 2018. URL: https:/www.nytimes.com/2018/03/01/business/trumptariffs.html.

Trevelyan, L. 2020. Is the World Entering a New Cold War? BBC, September 22. URL: https://www.bbc.com/news/world-us-canada-54244011. October 20, 2020.

Waltz, K. 1979. Theory of International Politics. Reading, MA: Addison-Wesley.

Weede, E. 2010. The Capitalist Peace and the Rise of China: Establishing Global Harmony by Economic Interdependence. International Interactions 36 (2): 206-213.

Wendt, A. 1992. Anarchy is what States Make of it: The Social Construction of Power Politics. International Organization, 46 (2): 391-425.

Wendt, A. 1995. Constructing International Politics. International Security, 20 (1): 71-81. https://doi.org/10.2307/2539217.

White House. 2018a. Presidential Proclamation on Adjusting Imports of Steel into the United States. Whitehouse,gov, March 8. URL: https://www.whitehouse.gov/presidential-actions/ presidential-proclamation-adjusting-imports-steel-united-states/. Accessed October 28, 2020.

White House. 2018b. Statement on Steps to Protect Domestic Technology and Intellectual Property from China's Discriminatory and Burdensome Trade Practices. White House, May 29. URL: https://www.whitehouse.gov/briefings-statements/statement-steps-protect-domestic-technology-intellectual-property-chinas-discriminatory-burdensome-trade-practi ces/. Accessed October 28, 2020.

White House, 2017. Remarks by President Trump at Business Event with President Xi of China (November 9, 2017) - https://www.whitehouse.gov/briefings-statements/remarkspresident-trump-business-event-president-xi-chinabeijing-china/

Wohlforth, W. C. 1993. The Elusive Balance: Power and Perceptions during the Cold War. New York: Cornell University Press.

World Bank. 2020. World Bank national accounts data, and OECD National Accounts data files (2020). GDP growth (annual \%) - China. URL: https://data.worldbank.org/ indicator/NY.GDP.MKTP.KD.ZG?locations=CN. Accessed October 10, 2020.

Wong, D., and Koty, A. Ch. 2020. The US-China Trade War: A Timeline. China Briefing. URL: https://www.china-briefing.com/news/the-us-china-trade-war-a-timeline/.

World Economic Forum. 2018. Future of Consumption in Fast-Growth Consumer Markets: China. Insight Report: A report by the World Economic Forum's System Initiative on Shaping the Future of Consumption. URL: http://www3.weforum.org/docs/WEF Future_of_Consumption_in_Fast_Growth_Consumer_Markets_China.pdf.

Woo, S., and O'Keeffe, K. 2018. Washington Asks Allies to Drop Huawei. World Street Journal, November 23. URL: https://www.wsj.com/articles/washington-asks-allies-todrop-huawei-1542965105. Accessed on 20 May 2020. 
WTO. 2016. Report on G20 Trade Measures (Mid-October 2015 to Mid-May 2016). URL: https://www.wto.org/english/news_e/news16_e/g20_wto_report_june16_e.pdf.

Xue, Y., and Chen, C. 2020. The US-China Tech Cold War has Turned Hot - but would a Biden Presidency Change Things for Huawei and Others? SCMP, September 16. URL: https://www.scmp.com/tech/big-tech/article/3101636/us-china-tech-cold-war-has-turnedhot-would-biden-presidency-change. Accessed October 28, 2020.

Yaqing, Q. 2010. International Society as a Process: Institutions, Identities, and China's Peaceful Rise. The Chinese Journal of International Politics 3 (2): 129-5.

Yoshida, J. 2020. US-China Cold War: How Did We Even Get Here? EET Asia, August 3. URL: https://www.eetasia.com/us-china-cold-war-how-did-we-even-get-here/. Accessed October 22, 2020.

Zhang, Y. 2018. The US-China Trade War: A Political and Economic Analysis. Indian Journal of Asian Affairs 31 (1/2): 53-74. 